\title{
Profile of Teachers' Technique in Teaching Division of Natural Number at Grade IV Deaf Students of State Elementary Special-Needs-School of Marawola
}

\author{
Sudarman Bennu \\ Universitas Tadulako \\ Palu, Indonesia \\ sudarmanbennu@gmail.com
}

\author{
Nur Afni \\ Universitas Tadulako \\ Palu, Indonesia \\ nurafniyusrin@gmail.com
}

\begin{abstract}
The purpose of this study is to obtain a description of techniques that teacher uses in teaching natural number division at grade IV deaf students of state elementary special-needs-school (SDLB Negeri) of Marawola. The type of this study is qualitative. The data gathering technique used in this study is such video recording, interview, and documentation. The research results show that teacher teaches natural number division by applying total communication technique, that is, the combination of signal and oral languages as well as visual aids like pens. The teacher teaches natural number division using two ways, that is, repeated subtraction and partition.
\end{abstract}

\section{Keywords—profile; deaf; division of natural number}

\section{INTRODUCTION}

Mathematics is a universal science underpinning the development of modern technology, having a significant role in a variety of disciplines and evolving power of human thought [1]. It also plays a great role in developing human's way of thinking as well as in solving problems in daily life. Therefore, it is taught in early ages and must be taught in all educational levels either in normal school or special need school. Thus, teachers should have teaching ability associated with students' condition with special needs in order that they can understand lesson as normal students can do.

A place where students with special needs learn and develop their knowledge and skills is SDLB Negeri Marawola. SLB Negeri Marawola consists of some classes based on students' need, starting with the elementary (SDLB) until state senior high school with special-needs (SMALB) levels. The students' special needs at the schools are blind, deaf, mental retardation, and orthopedically handicapped. The teachers who teach at the schools require competency corresponding to the students' needs.

Students with special needs who perceive more difficulties in learning mathematics are deaf students. This is because they cannot hear sounds around them, as well as restricted in speaking and communicating (language). Deaf students are those who are in organ handicapped that is auditory organ. The ability restriction in communicating language will result in the students' learning [2]. This is in line with the statement that deaf students get more obstacles in speaking and language development caused by their auditory handicapped [3].

A mathematical topic which is essential for SDLB students to learn is natural number division. Limitation of language and speaking abilities make them lack in understanding the concept of division. As a consequence, they need aids from the teacher in learning division on natural numbers. Therefore, it is required teaching technique associating with the students' characteristics in order that they can acquire the concept well.

Based on the aforementioned outline, it was important to describe the profile of teachers' technique in teaching division of natural number at Grade IV deaf students of SDLB Negeri Marawola. The problem formula within this research is that what is the profile of teachers' technique in teaching division of natural number at Grade IV deaf students of SDLB Negeri Marawola?

\section{METHODS}

The research type was qualitative research. The research subject was a teacher of Grade IV Deaf Students at SDLB Negeri Marawola. Data were gathered using video recordings, interview, field notes, and documentation. The research instruments were the researchers themselves as the main instrument, and supporting instruments comprising interview protocol and some electronic devices, like handphone, which was used to record a conversation between researchers and teacher and digital camera which was used to record teacher and students activities during instructional process.

Analysis of the qualitative data on the profile of profile of teachers' technique in teaching division of natural number at Grade IV Deaf Students of SDLB Negeri Marawola was by reducing data, displaying data and drawing a conclusion [4]. The credibility of the data was examined through method triangulation, i.e. attempt to find the consistency of data acquired from video recordings and interview.

\section{RESULTS AND DISCUSSION}

Teaching and learning process in this research comprised three activities those are introduction, main, and closing activities. Within introduction activity the teacher opened lesson by saying greetings and then preparing students to learn. 
The teacher opened learning activities by saying "Selamat pagi" or "Good Morning" along with making fist the righthand fingers, and then lifting it while taking thumb touch the right forehead, and then moving the thumb to the front. The movement means good morning. The students then responded it by shaping letter "W" using right-hand as shown in KS01, and then taking the forefinger to the right forehead, then moving it to the front.

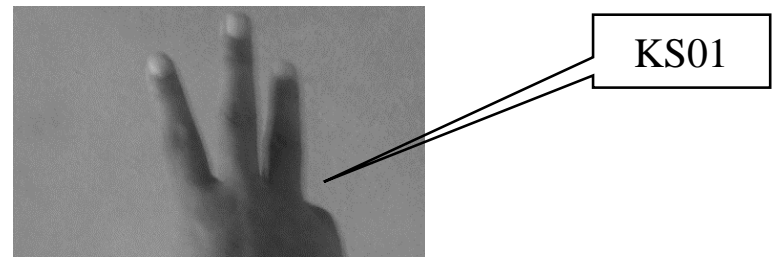

Fig. 1 Letter W

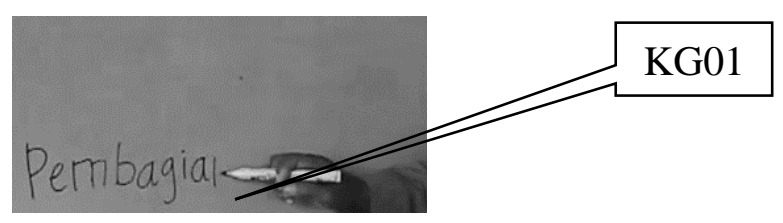

Fig. 2 Teacher wrote the lesson

Next, it concerned the main activities. Here, the teacher immediately taught the lesson to the students and provided them with some examples and exercises to be worked with. The teacher went over the lesson which would be learned that is division by writing the word "pembagian" or "division" on the whiteboard, as shown in KG01. And then the teacher taught division to the students through pen-assisted-question example as the concrete media. The questions concerning the division of natural number that the teacher taught were $2 \div 1$; $4 \div 2 ; 6 \div 2$; and $6 \div 6$. She taught division $2 \div 1$ through the following steps: (1) she wrote the question $2 \div 1$ on the whiteboard; (2) she put two pens on a student table, and then invited students to count the number of pens by appointing to the pens while saying one, two; (3) she took one pen to separate them one another while saying one, after that she took the other one and then separating them while saying two. Further, she lifted two right-hand fingers as the quotient of 2 $\div 1$. However for the question $4 \div 2$ she taught division with the different way that is by grouping pen. She also taught division $6 \div 2$ and $6 \div 6$ with the same way. To make it more distinct, it would then be explained as the following. She taught division $4 \div 2$ as we can see in Fig. 1, 2, 3, and 4 . Meanwhile, division $6 \div 2$ was as we can see in Fig. 5, 6, 7, and 8 .

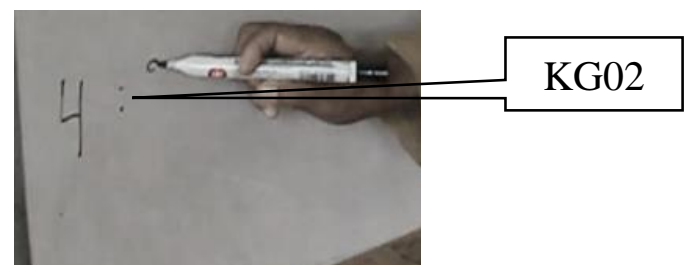

Fig. 3 The teacher wrote $4 \div 2$

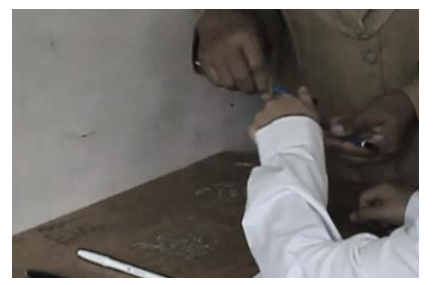

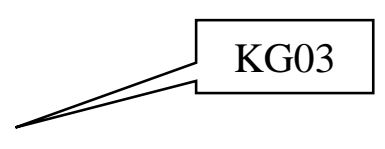

Fig. 4 The teacher put the pens

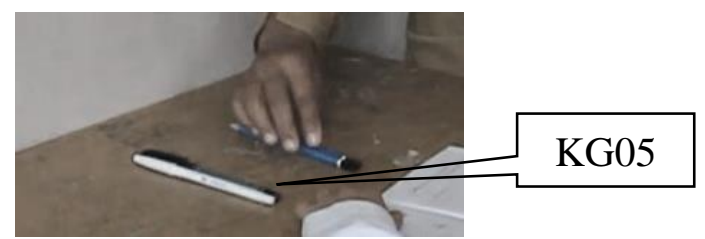

Fig. 5 Theteacher grouped the pens

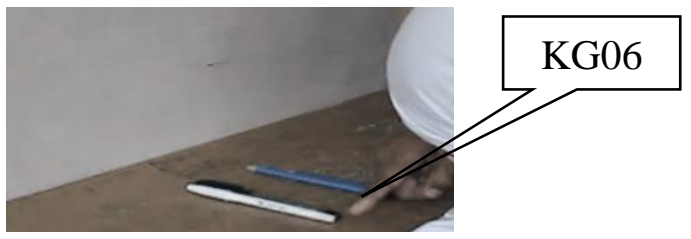

Fig. 6The teacher appointed to the quotient of 4 $\div 2$

The teacher taught division of $4 \div 2$ to the students by means of the following steps: (1) the teacher wrote $4 \div 2$ on the whiteboard (KG02), as shown in Fig. 3; (2) the teacher and students simultaneously put their pens one by one on the table while counting by saying (one, two, three, four), and then the teacher lifted up her right-hand with the thumb bent up and the other four fingers remained standing up indicating that number 4 means the number of pens (KG03 \& KS02), as displayed in Fig. 4; (3) the teacher said that it was divided by two, and beckoning number two with right-hand fingers by bending up little finger, ring finger, and thumb, whereas the forefinger and middle finger were standing up; (4) the teacher organized pens into two groups and in each group there existed two pens (KG04), as shown in Fig. 5; (5) the teacher asked "sama dengan berapa?" or "how many?". And then the teacher appointed the number of pens in each group by beckoning number two by using fingers and then saying "it is equal to two" (KG05), as shown in Fig. 6. The researchers interviewed the teacher to get more information, as presented in the following transcripts:

\section{WR01P : selanjutnya bagaimana ibu mengajarkan pembagian $4 \div 2$ ?}

[Next, how do you teach division $4 \div 2$ ?]

WR02G : seperti tadi empat pulpen saya letakan di atas meja siswa terus membilang dibantu dengan isyarat jari (satu, dua, tiga, empat). Kemudian saya pisahkan pulpen menjadi dua kelompok dan setiap kelompok itu mendapat dua pulpen.

[As I did, I put four pens on the students' table, and then counting with finger aids (one, two, three, and four). And then I separated them into 
two groups, and in each group there are two pens].

WR03P : mengapa ibu memisahkan pulpen kedalam dua kelompok?

[Why do you separate the pens into two groups?]

WR04G : karena sesuai dengan bilangan pembaginya 2 maka pulpen dipisahkan dalam dua kelompok.

[Because it is suitable with the numerator 2, so the pens are separated into two groups]

WR05P : selanjutnya bagaimana ibu menjelaskan hasil baginya?

[Further, how do you explain the quotient?]

WR06G : saya jelaskan hasil baginya kepada siswa, dengan menunjuk dua pulpen yang terdapat pada masingmasing kelompok. Sehingga siswa mengerti bahwa hasil baginya adalah banyaknya pulpen yang terdapat pada kelompok.

[I explain the quotient to the students by appointing two pens that exist in each group. Thus, they can understand that the quotient is the number of pens existing in group]

The interview results showed that the teacher taught division $4 \div 2$. She did it by taking and putting four pens on the students' table. After that, she invited students to count the number of pens by appointing (one, two, three, and four) (WR02G). And then she took the pens and then grouping them into two parts which consisted of two pens in each group. Subsequently, she got students to count the number of pens in each group that is there exists two constituting the quotient (WR03G).

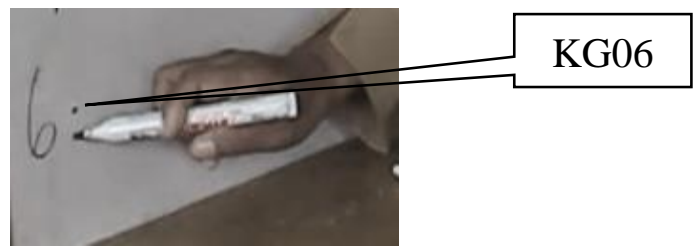

Fig. 7 The teacher wrote $4 \div 2$ whiteboard

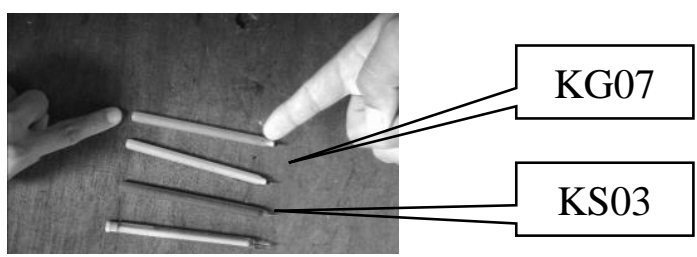

Fig. 8 The teacher put the pens on the students' table

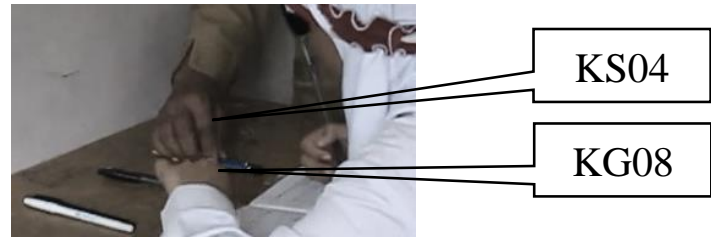

Fig. 9 Teacher and students grouped pens

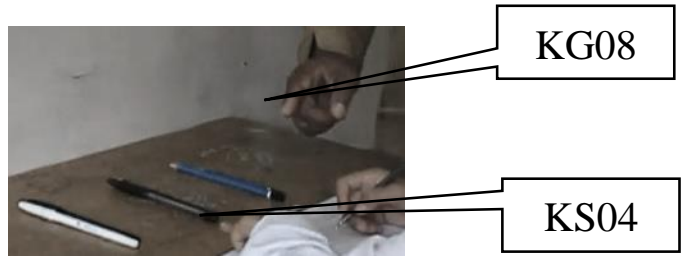

Fig. 10 The teacher appointed the quotient of $6 \div 2$

The teacher taught division $6 \div 2$ through the following stages: (1) the teacher wrote a question on the whiteboard (KG06), as shown in Fig. 7; (2) the teacher put six pens on the students' table, and then asking the students to count the number of pens while saying, "come on ... count and bend up your four right-hand fingers and let your little finger stands up". Further, the teacher with the students count the number of pens together by appointing the pens on the table through beckoning fingers for number one to six (KG07 \& KS03), as shown in Fig. 8; (3) the teacher separated two pens while counting by saying one, and then she drew on and separated again two pens while counting by saying two, and then she drew on and separated them again two pens while counting by saying three (KG08 \& KS04), as shown in Fig. 9. Thus, the teacher took two pens for three times constituting the quotient of $6 \div 2$ (KG09 \& KS05). The researchers then interviewed the teacher to get more information, as presented below:

WR07P : bagaimana cara ibu mengajarkan pembagian $6 \div 2$ kepada siswa deaf?

[How could you teach division $6 \div 2$ to deaf students?]

WR08G : iya, saya letakan enam pulpen di atas meja siswa setelah itu saya ajak siswa menghitung kembali banyaknya pulpen dengan menunjuk pulpen satu per satu lalu membilang dengan isyarat jari tangan kanan. Kemudian saya ambil dua pulpen pisahkan, lalu saya ambil lagi dua pulpen pisahkan, setelah itu saya ambil lagi dua pulpen pisahkan. Jadi ada tiga kali mengambil dua pulpen. Jadi hasil baginya sama dengan tiga.

[I put six pens on the students' table, and then asking them to recount the number of pens by appointing to the pens one by one while counting by beckoning with right-hand fingers. Further, I separated the pens. I firstly took two pens, and then taking more two pens, at last I took again two pens. Thus, I took two pens for three times, and the quotient is three]

WR09P : kemudian bagaimana cara ibu menjelaskan hasil baginya kepada siswa? 
[And then how could you explain the quotient to the students?]

WR10G : saya mengajak siswa membilang banyaknya kegiatan memisahkan dua pulpen tersebut dengan menunjuk kelompok pulpen, sehingga banyaknya kegiatan tersebut ada tiga kali dilakukan jadi hasil baginya sama dengan tiga.

[I had them count the number of activities in counting two pens by appointing to the group of pens. The activities are done for three times, so the quotient is three]

The interview results showed that the teacher taught division $6 \div 2$ by putting six pens on the students' tables. She then asked students to recount the number of pens by appointing to the pens by beckoning the right-hand fingers. Further she separated two pens, and then she took and separated more two pens, furthermore, she separated again two pens. Thus the teacher separated pens for three times where each separation consisted of two pens. The number of separations constituted the quotient of $6 \div 2$ (WR08G \& WR10G).

The teacher also provided them with some exercises on the division of natural numbers that is $8 \div 2,8 \div 4$, and $8 \div 8$. One of the exercises that the students did was $8 \div 2$, as shown in the Figures below.

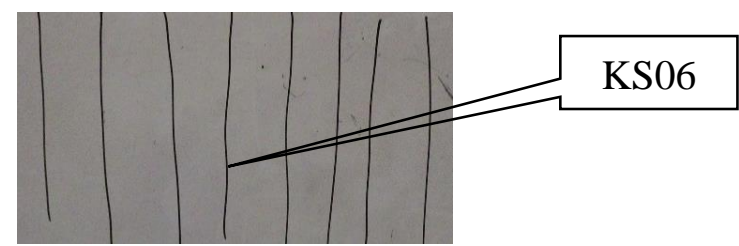

Fig. 11 The students drew the stakes

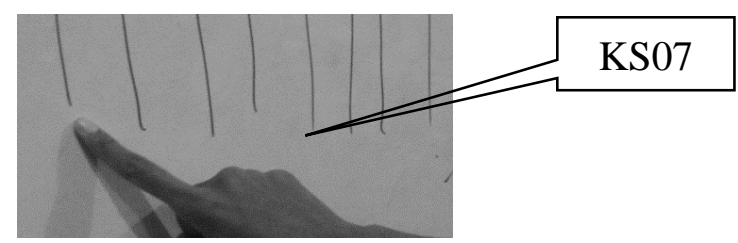

Fig. 12 The students appointed to the stakes

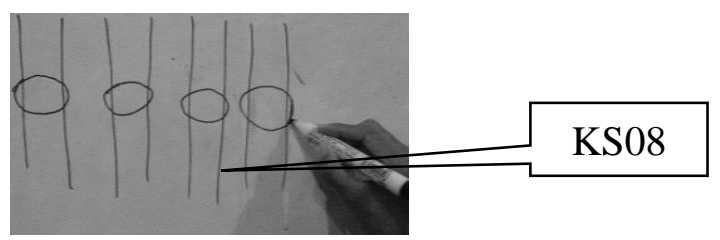

Fig. 13 The students circled the stakes

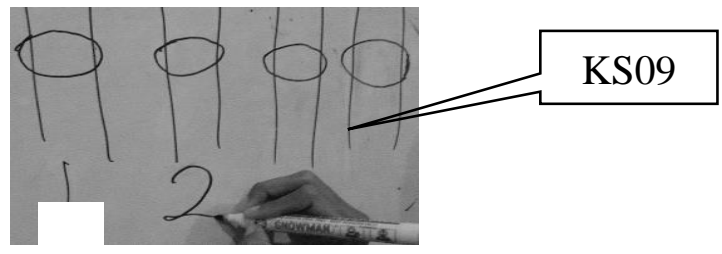

Fig. 14 The students wrote group of stakes

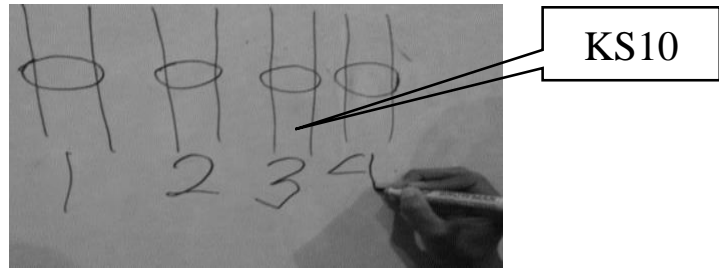

Fig. 15 The students wrote group of stakes

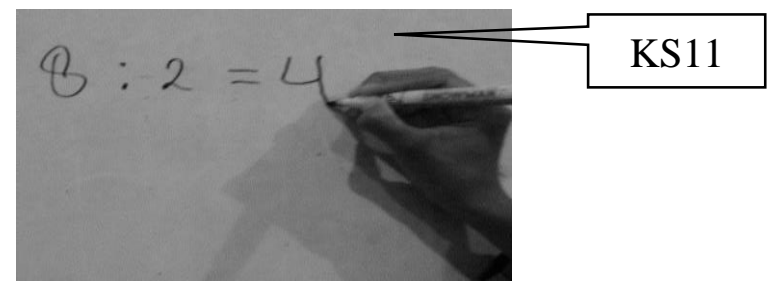

Fig. 16 The students wrote the quotient

The students carried out question $8 \div 2$ through the following stages: (1) the students drew as many as eight stakes on the whiteboard suitable with the number divided (KS06), as displayed in Fig. 11; (2) they then counted the stakes they drew by appointing one by one to the stake while pronouncing it aloud (KS07), as shown in Fig. 12; (3) the students circled in every two stakes corresponding to the divisor 2 (KS08), as shown in Fig. 13; (4) the students wrote each group of stakes they had circled (KS09 \& KS10), as presented in Fig. 14 \& 15; (5) students wrote number 4 on the whiteboard as the quotient of $8 \div 2$ (KS11), as displayed in Fig. 16 .

The teacher closed the learning activities by noticing to the students by saying "be more diligent to learn at home" or "rajin belajar lagi di rumahya" while using signal language that is making form as triangular with her two hands. During the instructional process the teacher taught the students by using oral and signal languages in communicating with the deaf students.

The teacher opened the lesson by saying "selamat pagi" by bending up her right-hand fingers and then lifting it while taking thumb touch the right forehead, and then moving the thumb to the front. This aimed to develop students' religious attitude. Further, the teacher went over the lesson on "division" which would be learned by writing the word on the whiteboard. The delivery of the lesson aimed at telling students the lesson they would learn. Once writing the topic of the lesson they would learn, the teacher should told them the learning objectives and goals, motivation words, apperception, as well as control their attendance. However the teacher, as the research subject, did not do the activities. She immediately taught the division of natural number to the students, because she just focused on the lesson which would be taught.

During the instructional process, the teacher interacted with the deaf students' using signal and oral languages like speaking and body motion. The students could understand the lesson by boxing the body motion and facial expression on the oral and signal languages. The use of oral and signal languages in an instructional process was an application of total communication technique. Through the total communication, 
the students were aided in understanding the lesson taught by the teacher. This is in line with what [5] state that one of technique that a teacher can apply on deaf students is total communication, i.e. a teacher attempts to go over a lesson through oral and signal languages so that making students easier to understand. This implies that the total communication may be applied on the deaf students because they cannot hear sounds.

The teacher taught division of natural number through some question examples by using repeated subtraction. The first step was that the teacher put pens on the students' table as many as the number divided while counting the number of the pens by using signal and oral languages. That was conducted to give insight to the students about the number of pens divided. The second step was that the teacher took pens as many as the repeated divisor until completed, where every time taking pens, the teacher counted by beckoning with fingers. The aim was in order that students could understand the number of teacher's activities in taking pens suitable with the divisor number constituting the quotient of a division. The questions that were taught by the teacher using repeated subtraction were division $2 \div 1 ; 6 \div 2$, and $6 \div 6$.

The teacher taught division $6 \div 2$ by putting six pens on the students' table. She then asked the students to count the number of pens on the table by appointing one by one to the pens by beckoning fingers from number 1 through 6 . After that the teacher took two pens and separated them while counting one and beckoning with finger for number one, and then the teacher retook and separated two pens while counting two and beckoning with finger for number two, and then for the next three times, the teacher retook and separated two pens while counting three and beckoning with finger for number three. Thus, the teacher took two pens for three times constituting the quotient of $6 \div 2$. This is in line with [6] proposing that division can also be interpreted as the repeated subtraction of the same number, i.e. the divided number was subtracted repeatedly by the divisor number until ended up. The number of subtractions which was conducted until the divided number became zero was actually the quotient. This is also supported by [7] in his proposition that division can be done by using repeated subtraction until the remainder is zero. The quotient is shown through how many times subtracted from the same number.

The teacher also taught division of natural number $a \div b$ through partition i.e. dividing a group of objects into as many as the number of objects in group $b$. The question taught by the teacher used partition was $4 \div 2$. She taught division $4 \div 2$ by taking four pens and then putting them on the students' table while counting the number of pens (one, two, three, and four) by appointing to the pens beckoning with the finger for number one through four. Further, she grouped the pens into two groups where in each group consisted of two pens. Furthermore, she had students count the number of pens existing in each group of pens on the students' table by appointing that there were two pens in each group constituting the quotient. This is in line with what stated by [8] and [9] that division $a \div b$ means there is a group of object as many a divided fairly (with the same quantity) as b groups, such that the quotient is the number of object existing in group $b$. This is also in accordance with [10] stating that division of a number a divided by a number $b$ means the number $a$ is divided fairly into $b$ groups, such that the quotient is the number of quantities in each of $b$ groups.

The teacher also wrote some exercises on the whiteboard for students to work with the aim to evaluate students' understanding on the division of natural number. The students carried out questions given by the teacher on the whiteboard through some steps. The first step, the students drew stakes on the whiteboard associated with the divisor number. The second step, they counted by appointing one by one to the stakes that they had drawn on. The third step, they circled the stakes suitable with the divisor number. The fourth step, they counted while writing the number of groups of stakes that they had circled. The fifth step, they wrote the quotient on the whiteboard. In the closing activity, the teacher checked the students' work, and then closing the learning activities by noticing to the students using signal language while saying "be more diligent to learn at home!".

The teacher taught division of the natural number by using visual aids such pen. A pen is one of object around students that can assist them to understand the lesson taught as well as enhance their interest and learning motivation. This associated with what [11] proposed that objects existing around students can help them, grow their interest and learning motivation. The use of pen aimed to help the deaf students do directly division operation in order that they could understand the mathematical concept taught. This corresponds to the statement by [12] that visual aids can help teacher simplify abstract concept into concrete form so that it becomes easier for students to understand. This also associates with the thesis by [13] that students learn to understand concept through concrete objects around them. This is in accordance with Bruner's theory that students are asked to find the concept of division on natural number through three steps, that is, using objects or things directly as inactive phase, and then continued to the iconic and symbolic phases.

Deaf students are those with an auditory disturbance so that students cannot hear sound or voice around them. This also happens to the deaf students when learning. They cannot hear voice from teachers teaching them. Nevertheless, they just can box teacher's body motion to understand the lesson taught. The deaf students learn by only focusing on eyesight. Thus they learned only by focusing on the things visible to them. This was in accordance with what experts said that "What I hear, I forget; what I hear, see, and ask questions about or discuss with someone else, I begin to understand" [14]. There are some reasons that children forget the things they have heard. One of them is the difference of speaking speed level of a teacher and that of hearing ability level of a student. Therefore the deaf students tend to understand the lesson taught through which they see due to the low level of their hearing ability.

\section{CONCLUSION}

The conclusion of this article is that the teacher taught division of natural number to deaf students using repeated subtraction and partition with a visual aid such pen. During the instructional process, the teacher used total communication technique that is combining signal and oral languages, so the 
students become easier in understanding division of natural number taught by the teacher. Thus, the researchers can then suggest to teachers or prospective teachers in order to consider at least two points when teaching the deaf students. First, a teacher should teach mathematics by considering mathematics ability that the students with special-need have in order that a teacher can design learning activities that correspond to students' ability. Thus students are expected to be able to acquire the lesson taught well. Second, a teacher should know the characteristics of deaf students in order to be able to justify the appropriate teaching technique, media as well as visual aids to help students become more understand the lesson taught.

\section{ACKNOWLEDGMENT}

The authors highly appreciate the teacher, principal, and grade IV deaf students of SDLB Negeri Marawola for their support and participation in this research.

\section{REFERENCES}

[1] Depdiknas. 2006. Kurikulum Tingkat Satuan Pendidikan (KTSP) Deaf. Jakarta: Direktorat Jendral Pendidikan Dasar dan Menengah.

[2] Widjaya, A. 2012. Memahami Anak Tunarungu. Yogyakarta: Familia.

[3] Ginting, F. 2012. Meningkatkan Kemampuan Mengenal Konsep Bilangan 1-10 melalui Permainan Bowling Plastik bagi Anak Tunarungu Ringan. Jurnal Ilmiah Pendidikan Khusus [online]. Retrieved from: http://ejournal.unp.ac.id/index.php/ju pekhu. [28 April 2016].

[4] Miles, M. B. \& Huberman, A. M. (1992). Analisis Data Kualitatif: Buku Sumber tentang Metode-Metode Baru. Translated by Tjetjep Rohendi Rohidi. Jakarta: UI-Press.

[5] Bilqis. 2012. Memahami Anak Tuna Wicara. Yogyakarta: Familia.
[6] Putri \& Siregar. 2009. Matematika untuk Siswa SD/MI Kelas III. Jakarta: Pusat Perbukuan Departemen Pendidikan Nasional.

[7] Kristiyono, H. 2008. Mahir Perkalian dan Pembagian Bilangan Dasar melalui Metode Permainan Kartu. Jurnal Pendidikan Penabur No.10 Tahun ke-7. Retrieved from http://www.academica.edu. [28 July 2016].

[8] Raharjo. 2009. Pembelajaran Operasi Hitung Perkalian dan Pembagian Bilangan Cacah di SD. Yogyakarta: Departemen Pendidikan Nasional Direktorat Jenderal Peningkatan Mutu Pendidik dan Tenaga Kependidikan Pusat Pengembangan dan Pemberdayaan Pendidik dan Tenaga Kependidikan (PPPPTK) Matematika.

[9] Sulastri, A. 2012. Peningkatan Hasil Belajar Matematika dengan Menggunakan Media Kartu Perkalian dan Pembagian melalui Metode Demonstrasi pada Siswa Kelas II SD Negeri KENITEN Tahun Ajaran 2011/2012. Jurnal Pendidikan Universitas Kristen Satya Wacana Salatiga. Retrieved from: http://www.uksw.edu. [20 Juni 2016].

[10] Diu, A. 2015. Deskripsi Penggunaan Metode Demonstrasi dalam Melakukan Perkalian dan Pembagian Bilangan Asli di Kelas II SD Negeri 1 Telaga Kabupaten Gorontalo. Jurnal Pendidikan Guru Sekolah Dasar [online]. Retrieved from: http: //kim.ung.ac.id/index. php/KIMFIP/article. [30 Agustus 2016].

[11] Suyamti, S. 2012. Meningkatkan Kemampuan Pemahaman Konsep Pembagian Bilangan dengan Penggunaan Media Asli pada Anak Tuna rungu. Jurnal Ilmiah Pendidikan Khusus, Vol. 1. Retrieved from: http://ejournal.unp.ac.id/ index.php/ jupekhu. [2 August 2016].

[12] Sunardjo. 2009. Pemanfaatan Alat Peraga Matematika pada Pembelajaran di SD. [Online]. Retrieved from: http://www.slideshare.net/NASuprawoto/pemanfaatan-alat-peragamatematika-dalam-pembelajaran-di-sd. [28 June 2016].

[13] Nurngaeni, S. 2013. Penerapan Teori Bruner untuk Meningkatkan Pemahaman Konsep Pembagian Bilangan Asli Siswa Kelas II SD Negeri 3 Bajong Bukateja Purbalingga. Jurnal Pendidikan Universitas Negeri Yogyakarta. Retrieved from: http://ejournal.uny.ac.id. [25 August 2016].

[14] Silberman, M. 2005. Active Learning 101 Strategi Pembelajaran Aktif. Yogyakarta: Pustaka Insan Madani 